Document downloaded from:

http://hdl.handle.net/10251/61121

This paper must be cited as:

Pérez Ruiz, R.; Domingo, LR.; Sáez, JA.; Jiménez Molero, MC.; Miranda Alonso, MÁ. (2012). Ring splitting of azetidin-2-ones via radical anions. Organic and Biomolecular Chemistry. 10(39):7928-7932. doi:10.1039/c2ob26528a.

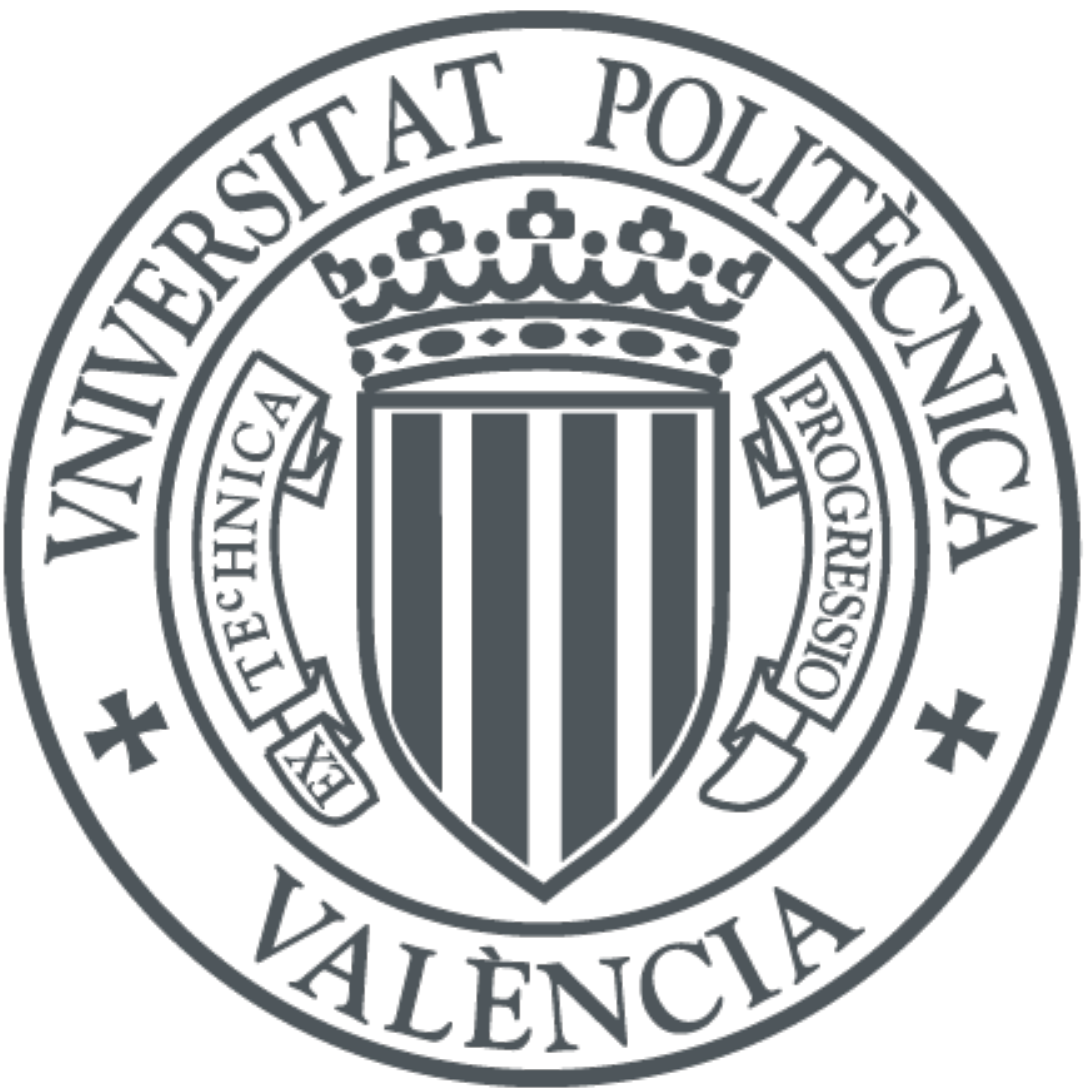

The final publication is available at

http://dx.doi.org/10.1039/c2ob26528a

Copyright Royal Society of Chemistry

Additional Information 


\title{
Ring Splitting of Azetidin-2-ones via Radical Anions
}

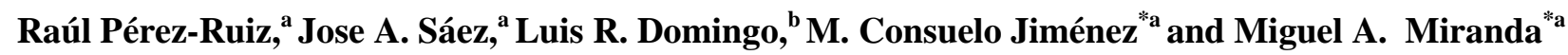

5 The radical anions of azetidin-2-ones, generated by UV-irradiation in the presence of triethylamine,
undergo ring-splitting via N-C4 or C3-C4 bond breaking, leading to open-chain amides. This reactivity
diverges form that found for the neutral excited states, which is characterised by $\alpha$-cleavage. The
preference for $\beta$-cleavage is supported by DFT theoretical calculations on the energy barriers associated
with the involved transition states. Thus, injection on one electron into the azetidin-2-one moiety
10 constitutes a complementary activation strategy which may be exploited to produce new chemistry.

\section{Introduction}

The chemistry of azetidin-2-ones has attracted considerable interest over the last decades, ${ }^{1}$ mainly due to the important biological activity of this family of compounds ( $\beta$-lactams),

15 noteworthy their widespread clinical application as antibacterial agents. $^{2}$

Azetidin-2-ones can be used as building blocks in organic synthesis by exploiting the possibilities of cleavage at any of the single bonds of the four-membered ring. In this context, reductive

20 cleavage has been achieved by palladium-catalysed hydrogenolysis $^{3}$ or treatment with hydrides, whereas oxidative ring opening has been performed by treatment with ozone. ${ }^{4}$ By contrast, the photoreactivity of azetidin-2-ones has received much less attention, ${ }^{5}$ and in fact these compounds are generally 25 considered nearly photostable.

Interestingly, the behaviour of radical anions of azetidin-2ones remains unexplored, in spite of their potential to exhibit new chemistry; in fact, injection of one electron to the ring system constitutes a different (and complementary) activation strategy. 30 Thus, photoredox catalysis via radical anions has shown potential for the development of synthetic methodologies. ${ }^{6 a}$ In addition, ring splitting of four-membered ring radical anions has been explored, both experimentally and theoretically, in connection with the repair of pyrimidine dimers in DNA by photolyases. ${ }^{6 \mathrm{~b}-\mathrm{g}}$

${ }_{35}$ With this background, the aim of the present work is to use triethylamine as donor for the generation of the radical anions of azetidin-2-ones $t$ - or $c$-1a-c upon UV-excitation. Phenyl substitution at $\mathrm{N}, \mathrm{C} 3 \mathrm{and} /$ or $\mathrm{C} 4$ has been chosen for convenience, in order to introduce light absorbing chromophore(s) and to 40 contribute to the stabilisation of the radical and anionic centres developed during a possible ring splitting process.

It will be shown that the most general result is actually $\beta$ cleavage, leading to open-chain amides. This reactivity diverges from that found for the neutral excited states, which is
45 characterised by $\alpha$-cleavage. The experimental results are supported by DFT calculations on the course of the reaction at the UB3LYP/6-31+G(d) level of theory.

\section{Results and Discussion}

In order to check the feasibility of electron transfer from $\mathrm{Et}_{3} \mathrm{~N}$ to 50 the singlet excited state of $\mathbf{1 a - c}\left({ }^{1} \mathbf{1} \mathbf{a}-\mathbf{c}^{*}\right)$, the fluorescence spectra of the latter were recorded in acetonitrile in the presence and in the absence of the amine. Figure 1 shows the results obtained with $c \mathbf{- 1 a}$, as a representative example. A very week emission band was observed with maximum at ca. $340 \mathrm{~nm}$, which was 55 quenched by $\mathrm{Et}_{3} \mathrm{~N}$.

60

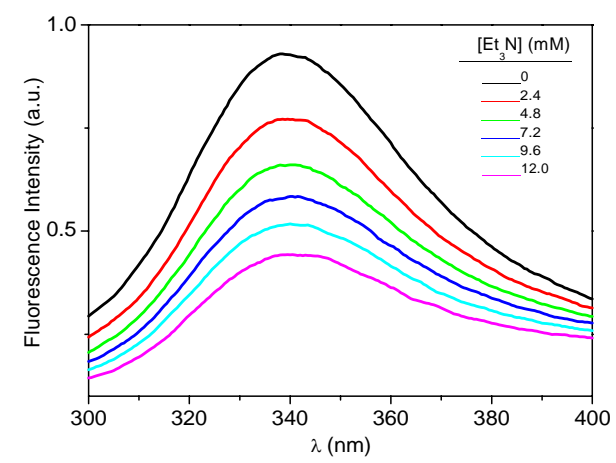

Fig. 1 Fluorescence spectra of $c$-1a at $3.310^{-5} \mathrm{M}$ concentration $\left(\lambda_{\mathrm{exc}}=254\right.$ $70 \mathrm{~nm}, \mathrm{MeCN}$, air) in the presence of increasing amounts of $\mathrm{Et}_{3} \mathrm{~N}$, from 0 to $12 \mathrm{mM}$.

From the intersection between the normalised emission and excitation bands, a singlet energy of $95 \mathrm{kcal} \mathrm{mol}^{-1}$ was determined. Furthermore, the reduction potential was measured 75 by means of cyclic voltammetry ${ }^{7}$ and found to be $-2.6 \mathrm{~V}$ vs SCE, in acetonitrile. With these data, application of the Rehm-Weller 


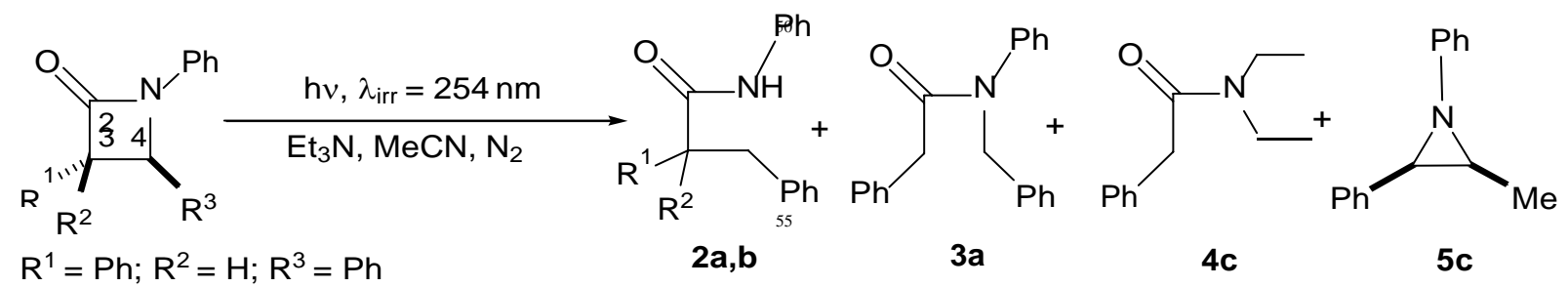

$t$-1a: $\mathrm{R}^{1}=\mathrm{Ph} ; \mathrm{R}^{2}=\mathrm{H} ; \mathrm{R}^{3}=\mathrm{Ph}$

$c$-1a: $\mathrm{R}^{1}=\mathrm{H} ; \mathrm{R}^{2}=\mathrm{Ph} ; \mathrm{R}^{3}=\mathrm{Ph}$

$t$-1 b: $\mathrm{R}^{1}=$ cyclopropyl; $\mathrm{R}^{2}=\mathrm{H} ; \mathrm{R}^{3}=\mathrm{Ph}$

${ }^{10} c-1 \mathbf{b}: R^{1}=\mathrm{H} ; \mathrm{R}^{2}=$ cyclopropyl; $\mathrm{R}^{3}=\mathrm{Ph}$

$t$-1c: $\mathrm{R}^{1}=\mathrm{Ph} ; \mathrm{R}^{2}=\mathrm{H} ; \mathrm{R}^{3}=\mathrm{Me}$

$c-1 c: R^{1}=H ; R^{2}=P h ; R^{3}=M e$

Scheme 1

equation ${ }^{8}$ confirmed that electron transfer from $\mathrm{Et}_{3} \mathrm{~N}$ to ${ }^{1} \mathbf{1 a}-\mathbf{c} *$ is indeed exergonic $\left(\Delta \mathrm{G}=-15 \mathrm{kcal} \mathrm{mol}^{-1}\right)$. For product studies, acetonitrile solutions of $t-\mathbf{1 a}-\mathbf{c}$ or $c$-1a-c containing a 50-fold excess of triethylamine were deaerated with nitrogen and 20 irradiated through quartz for 2 hours, with low pressure mercury lamps $\left(\lambda_{\text {irr }}=254 \mathrm{~nm}\right)$. The reaction mixtures were analysed by GC-MS, using biphenyl as internal standard; the results are shown in Scheme 1 and Table 1. In general, mass balances were expectedly poor for high conversions, due to the extensive 25 production of radicals and polymers derived therefrom. In the case of $t-\mathbf{1 a}$ or $c-1 \mathbf{a},{ }^{9}$ with three vicinal phenyl groups at $\mathrm{N}, \mathrm{C} 3$ and $\mathrm{C} 4$, only the open chain amides $2 \mathbf{a}^{10}$ and $\mathbf{3} \mathbf{a}^{11}$ were obtained as products. Their chemical structures were confirmed by comparison with authentic samples.

30

Table 1 Photolysis of 1a-c in the presence of triethylamine ${ }^{a}$

\begin{tabular}{ccccccc} 
Compound & $\operatorname{Conv}^{b}(\%)$ & $\mathrm{MB}^{c}(\%)$ & \multicolumn{6}{c}{ Product Distributioh $(\%)$} \\
\hline$t-\mathbf{1 a}$ & 91 & 30 & 73 & 27 & - & - \\
$c-\mathbf{1 a}{ }^{e}$ & 84 & 27 & 52 & 48 & - & - \\
$t-\mathbf{1 b}$ & 80 & 30 & 100 & - & - & - \\
$c-\mathbf{1 b}$ & 68 & 48 & 100 & - & - & - \\
$t-\mathbf{1 c}$ & 47 & 87 & - & - & 100 & - \\
$c-\mathbf{1 c}$ & 36 & 95 & - & - & 54 & 46
\end{tabular}

${ }^{a}$ 1a-c $=0.05 \mathrm{mmol}, \mathrm{Et}_{3} \mathrm{~N}=2.5 \mathrm{mmol}, \mathrm{MeCN}=5 \mathrm{~mL}, \mathrm{~N}_{2}, \lambda_{\text {irr }}=254 \mathrm{~nm} ;{ }^{b}$ Calculated from recovered 1a-c; ${ }^{c}$ Mass balance; ${ }^{d}$ Determined by GC MS using biphenyl as internal standard; errors were lower than $5 \%$ of the 35 stated values; ${ }^{e}$ This reaction was also carried out with $\mathrm{N}, \mathrm{N}$ dimethylcyclohexylamine as electron donor with similar results.

When azetidin-2-ones $t \mathbf{- 1 \mathbf { b }}$ and $c$-1b were photolysed in the presence of triethylamine only $\mathbf{2} \mathbf{b}$, with the unaltered cyclopropyl ${ }_{40}$ ring, was detected as a result of $\mathrm{N}-\mathrm{C} 4$ bond cleavage. The product was isolated by HPLC and fully characterised by ${ }^{1} \mathrm{H}-\mathrm{NMR},{ }^{13} \mathrm{C}-$ NMR and MS, as well as by X-Ray diffraction analysis (see Figure 2).

To check whether the absence of phenyl groups in vicinal 45 positions of the ring has any influence on the reactivity of the radical anions, azetidin-2-ones $t$-1c and $c$-1c were selected. Interestingly, their photolysis in the presence of triethylamine did not afford the expected open chain amides; instead, $t-\mathbf{1 c}$ and $c-\mathbf{1 c}$ reacted sluggishly, to give only products arising from
65 fragmentation $(\mathbf{4 c})^{12}$ and decarbonylation $(\mathbf{5 c}) .^{13}$

In the absence of triethylamine, under otherwise identical

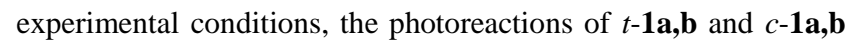
were markedly slower and gave $\mathrm{N}$-benzylideneaniline as the only detectable product. This is obviously the result of N-C2 plus C3-

${ }_{70} \mathrm{C} 4$ bond cleavage. As regards $t$-1c and $c$-1c, the absence of triethylamine did not result in significant changes, except for the lack of $\mathbf{4 c}$, whose formation can be attributed to nucleophilic trapping of phenylketene by the tertiary amine with concomitant loss of ethylene. ${ }^{14}$ Again, the decarbonylation product was only 75 observed in the case of the cis isomer, probably because the steric strain introduced by the substituents at $\mathrm{C} 3$ and $\mathrm{C} 4$ results in a slight disruption of the planar geometry of the precursor biradical generated by cleavage of the $\mathrm{N}-\mathrm{C} 2$ bond, difficulting formation of the ketene-imine pair. Thus, it seems that, even in the presence of 80 triethylamine, the reactions of $t-\mathbf{1 c}$ and $c-\mathbf{1 c}$ proceed directly from the neutral excited state, rather than from the radical anion. This was confirmed by photolysis of $t-\mathbf{1 c}$ in methanol, which led to formation of methyl phenylacetate, the trapping product of phenylketene. In agreement with expectations, in the case of $c$-1c 85 aziridine $\mathbf{5 c}$ was also obtained.

90

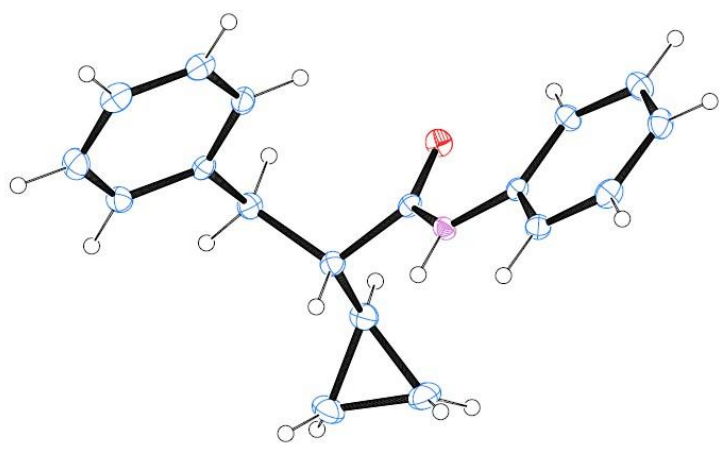

Fig. 2 X-Ray structure of the amide-like compound $\mathbf{2 b}$

100 A mechanistic rationalization of the obtained results is summarized in Scheme 2. After excitation of azetidin-2-ones to the singlet excited states, ${ }^{1} \mathbf{1} \mathbf{a}-\mathbf{c}^{*}$ would accept one electron from $\mathrm{Et}_{3} \mathrm{~N}$, to afford the corresponding radical anions 1a-c . Subsequent $\beta$-cleavage of the N-C4 or the C3-C4 bonds would 105 lead to the distonic radical anionic intermediates and ultimately to 
the open-chain amides $\mathbf{2} \mathbf{a}, \mathbf{b}$ or $\mathbf{3 a}$. In the case of $\mathbf{1 c}$, direct photolysis would ensue with $\alpha$-cleavage, affording $\mathbf{4 c}$ and $\mathbf{5 c}$.

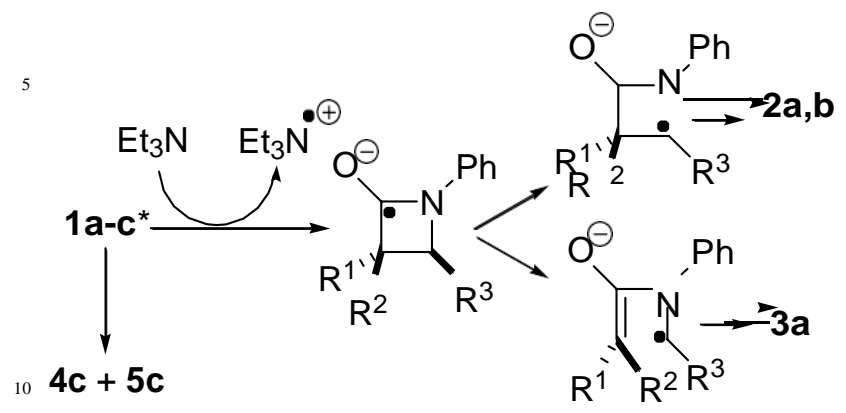

Scheme 2. Mechanistic pathways for ring splitting of the radical anions generated by photolysis of azetidin-2-ones in the presence of triethylamine

To understand the reactivity of radical anions $t-\mathbf{1 a -} \mathbf{c}^{\cdot-}$ and $c$ $\mathbf{1 a}^{-\mathbf{c}^{-}}$, theoretical calculations based on DFT methods at the UB3LYP/6-31+G(d) ${ }^{15}$ level of theory were performed. Solvent effects were considered through single-point calculations at gas-

${ }_{20}$ phase stationary geometries, using the self-consistent reaction field (SCRF) method based on the polarizable continuum model (PCM) of Tomasi's group. ${ }^{16}$
(11.0)

O $11.1 \mathrm{Ph}$

$11.6-\mathrm{N}^{\prime} 0.9$

(9.7)

$\mathrm{Ph}$ " $-0.4 \mathrm{Ph}$

$(-21.8)$

$t-1 \mathbf{a}$

(11.3)

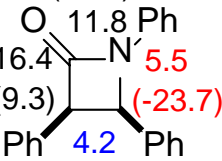

$(-19.4)$

$c-1 \mathrm{a}$
(8.2)

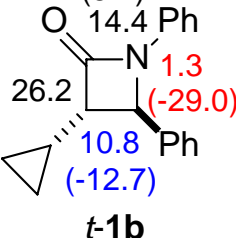

(9.4)

O $10.7 \mathrm{Ph}$

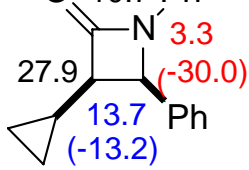

$c-1 \mathrm{~b}$
(12.5)

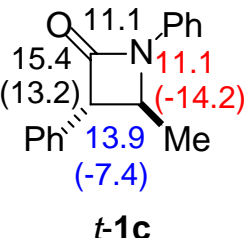

$(-9.2)$

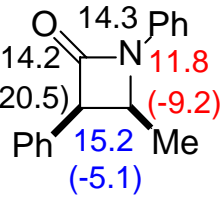

c-1c
${ }_{25}$ Fig. 3. UB3LYP/6-31+G(d) relative energies $\left(\mathrm{kcal} \mathrm{mol}^{-1}\right)$, in acetonitrile, associated with the transition states (and, in parentheses, the intermediates) for all the bond-breaking processes at the radical anions $t$ and $c-\mathbf{1 a -}-\mathbf{c}^{--}$

Four possible ring splitting pathways can be envisaged, namely ${ }_{30} \mathrm{~N}-\mathrm{C} 2, \mathrm{C} 2-\mathrm{C} 3, \mathrm{C} 3-\mathrm{C} 4$ and $\mathrm{N}-\mathrm{C} 4$ (see Figure 3). In $c$ - and $t-\mathbf{1 a}^{\cdot-}$, with three vicinal phenyl groups, the most favourable cleavages are those associated with the $\mathrm{N}-\mathrm{C} 4$ and $\mathrm{C} 3-\mathrm{C} 4$ bonds. Accordingly, a mixture of the corresponding open chain products (2a and 3a) was indeed obtained. At the radical anions $c$ - and $t$ ${ }_{35} \mathbf{1 b}^{\circ-}$, with two adjacent phenyl groups, cleavage of the $\mathrm{N}-\mathrm{C} 4$ bond is clearly favoured. This is in agreement with the fact that only one open chain product (2b) was experimentally obtained. Finally, the barriers associated with the four bond-breaking processes at $c$ - and $t \mathbf{- 1}^{\cdot-}$ are considerably higher, so no product 40 was detected arising from the radical anion. In general, formation of intermediates via $\mathrm{N}-\mathrm{C} 4$ or $\mathrm{C} 3-\mathrm{C} 4$ bond-breaking is exothermic ( -13 to $\left.-22 \mathrm{kcal} \mathrm{mol}^{-1}\right)$. A summarised energy diagram containing the data calculated for the most favourable reaction pathways of

$t-\mathbf{1 a}, \mathbf{b}^{-}$is shown in Scheme 3. A very similar trend is exhibited 45 by the corresponding cis isomers.

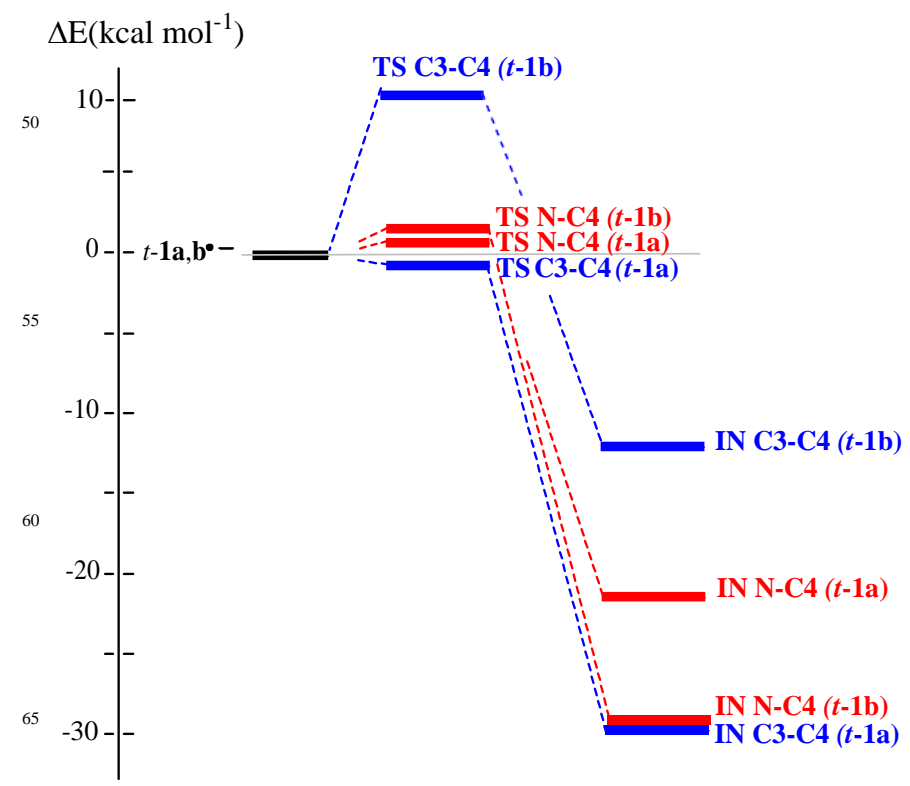

Scheme 3. Relative energies of the transition states and intermediates involved in ring splitting of $t-\mathbf{1} \mathbf{a}, \mathbf{b}^{\cdot-}$

The geometries of the intermediates involved in the ring splitting of $\mathbf{1} \mathbf{a}, \mathbf{b}^{-}$are shown in Figure 4. In all cases, the breaking bond is markedly elongated at this stage and, accordingly, the bond order is nearly zero. As regards location of 75 charge and spin, the highest accumulation of negative charge is found in the carbonyl-containing substructure $(\mathrm{N}-\mathrm{C} 2=\mathrm{O}$ or $\mathrm{C} 3-$ $\mathrm{C} 2=\mathrm{O}$, depending on whether ring splitting occurs at the $\mathrm{C} 3-\mathrm{C} 4$ or N-C4 bonds, respectively). Finally, the maximum value of spin density is always found at $\mathrm{C} 4$. The rest of charge and spin is 80 spread all over the structure, mainly due to delocalisation through the phenyl rings.

\section{Conclusions}

In summary, ring splitting of azetidin-2-ones via their radical 85 anions proceeds with $\beta$-cleavage of the $\mathrm{N}-\mathrm{C} 4$ and/or the $\mathrm{C} 3-\mathrm{C} 4$ bonds, leading to open chain amides. Theoretical DFT calculations have allowed us to characterise the involved transition states and intermediates, which support the experimentally observed reactivity. It has been shown that

90 injection of one electron into the azetidin-2-one moiety constitutes a complementary activation strategy, which may be exploited to produce new chemistry. 


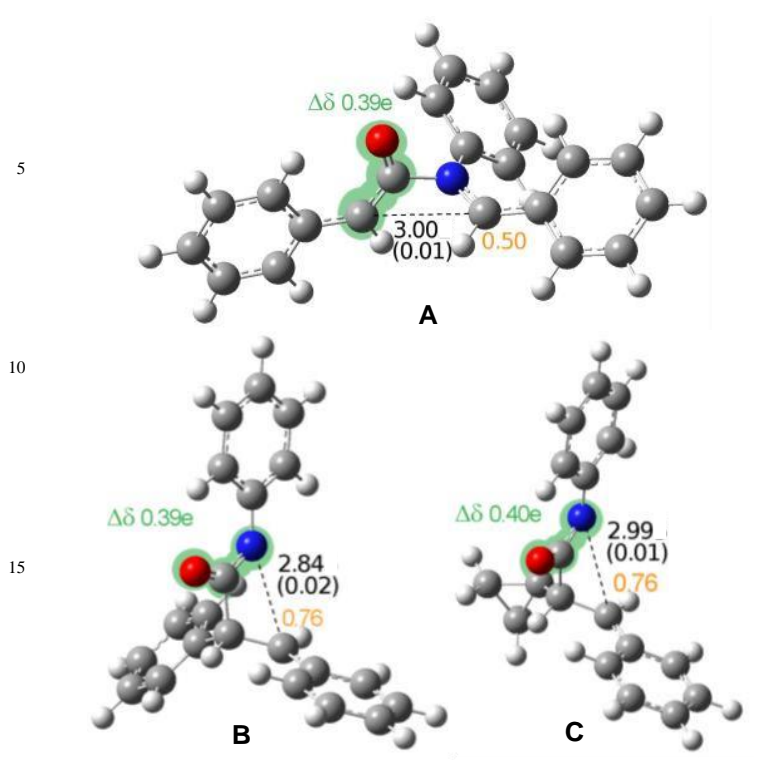

20 Fig. 4. Calculated geometries for the intermediates involved in the ring splitting processes of $\mathbf{1} \mathbf{a}, \mathbf{b}^{-}$. Key bond distances (in Angstroms) and bond order values (in parenthesis) are indicated in black. A: IN C3-C4 (t1a), B: IN N-C4 ( $t$-1a); C: IN N-C4 ( $t$-1b). Natural charge accumulated at $\mathrm{N}-\mathrm{C} 2=\mathrm{O}$ or $\mathrm{C} 3-\mathrm{C} 2=\mathrm{O}$ moiety with respect to the corresponding neutral 25 azetidin-2-one, is indicated in green. The Mulliken spin density at $\mathrm{C} 4$ is given in orange.

\section{Materials and Methods}

\section{Synthesis of the new compounds}

Azetidin-2-ones $t$-1a and $c$-1a, have been previously described 30 and characterised. ${ }^{9}$ Compounds $t-\mathbf{1 b}, c-\mathbf{1 b}, t-\mathbf{1 c}$ and $c$-1c were synthesised according to a procedure previously published for related compounds. ${ }^{17}$ Briefly, in the case of $t-\mathbf{1 b}$ and $c-\mathbf{1 b}$, a solution of cyclopropylacetylene $(2.0 \mathrm{mmol}, 132 \mathrm{mg})$ in DMF/pyridine $(8 \mathrm{~mL} / 2 \mathrm{~mL})$ was added to a mixture of $N-\alpha$ ${ }_{35}$ diphenylnitrone $(2.0 \mathrm{mmol}, 400 \mathrm{mg}), \mathrm{CuI}(0.2 \mathrm{mmol}, 95 \mathrm{mg})$ and $\mathrm{K}_{2} \mathrm{CO}_{3}(2.2 \mathrm{mmol}, 300 \mathrm{mg})$. The resulting mixture was stirred overnight at room temperature under $\mathrm{N}_{2}$ atmosphere, poured into water and extracted with diethyl ether. The organic phase was dried over $\mathrm{Na}_{2} \mathrm{SO}_{4}$ and the solvent evaporated under vacuum. The 40 residue was submitted to column chomatography on silica gel, using hexane/ethyl acetate as eluent (99:1 to 90:10), to afford $t$ $\mathbf{1 b}$ and $c-\mathbf{1 b}$.

A similar procedure was followed for the synthesis of $t$-1c and $c$-1c, using phenylacetylene ( $2.0 \mathrm{mmol}, 204 \mathrm{mg}$ ) and $N$-phenyl- $\alpha$ 45 (methyl)nitrone as reactants. The latter was generated in situ by addition of acetaldehyde $(2.4 \mathrm{mmol}, 105 \mathrm{mg})$ in $3 \mathrm{~mL}$ of $\mathrm{Et}_{2} \mathrm{O}$ to a mixture of $\mathrm{N}$-phenylhydroxylamine $(2.4 \mathrm{mmol}, 262 \mathrm{mg})$ and $\mathrm{K}_{2} \mathrm{CO}_{3}(5 \mathrm{mmol}, 690 \mathrm{mg})$ in $3 \mathrm{~mL}$ of $\mathrm{Et}_{2} \mathrm{O}$ at $0{ }^{\circ} \mathrm{C}$, during $1 \mathrm{~h}$.

Photoproduct $\mathbf{2 b}$ was obtained as follows: $t \mathbf{- 1 \mathbf { b }}(0.05 \mathrm{mmol}$, $5013.2 \mathrm{mg})$ was irradiated in the presence of $\mathrm{Et}_{3} \mathrm{~N}$ (2.5 mmol, 252 $\mathrm{mg}$ ) for $2 \mathrm{~h}$, using $\mathrm{MeCN}(5 \mathrm{~mL})$ as solvent. After evaporation of the solvent, final purification was done by HPLC (acetonitrile:water 80:20 v/v) and recrystallization in hexane.

\section{${ }_{55}$ Characterisation of the new compounds}

All new compounds were characterised by ${ }^{1} \mathrm{H}$ and ${ }^{13} \mathrm{C}$ NMR spectroscopy, as well as by high resolution mass spectrometry (HRMS). Their purity was confirmed by gas chromatography (GC) and high performance liquid chromatograpy (HPLC). A 60 summary of the most relevant data follows.

\section{trans-3-Cyclopropyl-1,4-diphenylazetidin-2-one ( $t$-1b)}

${ }^{1} \mathrm{H}-\mathrm{NMR}\left(300 \mathrm{MHz}, \mathrm{CDCl}_{3}\right.$ ) ( $\left.\delta, \mathrm{ppm}\right): 0.05$ (m, 2H), 0.39 (m, $3 \mathrm{H}), 3.08(\mathrm{~m}, 1 \mathrm{H}), 5.12(\mathrm{~d}, 1 \mathrm{H}, J=5.9 \mathrm{~Hz}), 6.98(\mathrm{~m}, 1 \mathrm{H}), 7.25$ $(\mathrm{m}, 9 \mathrm{H}) ;{ }^{13} \mathrm{C}-\mathrm{NMR}\left(75 \mathrm{MHz}, \mathrm{CDCl}_{3}\right)(\delta, \mathrm{ppm}): 2.5,3.8,6.7$, 65 58.8, 59.5, 117.1, 123.7, 126.9, 127.8, 128.4, 128.9, 135.6, 137.7, 166.7; Exact Mass (HRMS): required for $\mathrm{C}_{18} \mathrm{H}_{17} \mathrm{NO}: 264.1388$ $\left(\mathrm{MH}^{+}\right)$; found 264.1384.

\section{cis-3-Cyclopropyl-1,4-diphenylazetidin-2-one ( $c$-1b)}

${ }^{1} \mathrm{H}-\mathrm{NMR}\left(300 \mathrm{MHz}, \mathrm{CDCl}_{3}\right)(\delta, \mathrm{ppm}): 0.38(\mathrm{~m}, 2 \mathrm{H}), 0.58(\mathrm{~m}$, $702 \mathrm{H}), 1.13(\mathrm{~m}, 1 \mathrm{H}), 2.77$ (dd, $1 \mathrm{H}, J=2.5 \mathrm{~Hz}, J=7.9 \mathrm{~Hz}), 4.69$ (d, $1 \mathrm{H}, J=2.5 \mathrm{~Hz}), 6.96(\mathrm{~m}, 1 \mathrm{H}), 7.24(\mathrm{~m}, 9 \mathrm{H}) ;{ }^{13} \mathrm{C}-\mathrm{NMR}(75 \mathrm{MHz}$, $\left.\mathrm{CDCl}_{3}\right)(\delta, \mathrm{ppm}): 2.2,3.2,9.4,61.0,63.9,117.0,123.7,125.6$, 128.3, 129.0, 129.1 137.7, 138.0, 166.5; Exact Mass (HRMS): required for $\mathrm{C} \mathrm{H}$ NO: $264.1388\left(\mathrm{MH}^{+}\right)$; found 264.1393 . $18 \quad 17$

\section{5 trans-1,3-Diphenyl-4-methylazetidin-2-one $(t-1 \mathrm{c})$}

${ }^{1} \mathrm{H}-\mathrm{NMR}\left(400 \mathrm{MHz}, \mathrm{CDCl}_{3}\right)(\delta, \mathrm{ppm}): 1.12(\mathrm{~d}, \mathrm{~J}=6.3 \mathrm{~Hz}, 3 \mathrm{H})$, $4.51(\mathrm{p}, J=6.3 \mathrm{~Hz}, 1 \mathrm{H}), 4.71,(\mathrm{~d}, J=6.0 \mathrm{~Hz}, 1 \mathrm{H}), 7.12(\mathrm{t}, J=7.4$ $\mathrm{Hz}, 1 \mathrm{H}), 7.29-7.50(\mathrm{~m}, 9 \mathrm{H}) ;{ }^{13} \mathrm{C}-\mathrm{NMR}\left(100 \mathrm{MHz}, \mathrm{CDCl}_{3}\right)(\delta$, ppm): 15.2, 52.4, 57.9, 117.2, 124.1, 127.8, 128.8, 129.3, 129.4, ${ }_{80}$ 132.9, 137.7, 165.6; Exact Mass (HRMS): required for

$\mathrm{C}_{16} \mathrm{H}_{15} \mathrm{NO}$ : $238.1232\left(\mathrm{MH}^{+}\right)$; found 238.1233.

\section{cis-1,3-Diphenyl-4-methylazetidin-2-one (c-1c)}

${ }^{1} \mathrm{H}-\mathrm{NMR}\left(400 \mathrm{MHz}, \mathrm{CDCl}_{3}\right)(\delta, \mathrm{ppm}): 1.67(\mathrm{~d}, J=6.0 \mathrm{~Hz}, 3 \mathrm{H})$, $4.04(\mathrm{~d}, J=2.3 \mathrm{~Hz}, 1 \mathrm{H}), 4.16,(\mathrm{dq}, J=6.0 \mathrm{~Hz}, J=2.3 \mathrm{~Hz}, 1 \mathrm{H})$,

${ }_{85} 7.13,(\mathrm{t}, J=7.3 \mathrm{~Hz}, 1 \mathrm{H}), 7.29-7.46(\mathrm{~m}, 9 \mathrm{H}) ;{ }^{13} \mathrm{C}-\mathrm{NMR}(100 \mathrm{MHz}$, $\left.\mathrm{CDCl}_{3}\right)(\delta, \mathrm{ppm}): 18.4,56.7,62.2,117.3,124.1,127.5,127.8$, 129.1, 129.4, 135.2, 137.4, 165.2; Exact Mass (HRMS): required for $\mathrm{C}_{16} \mathrm{H}_{15} \mathrm{NO}$ : $238.1232\left(\mathrm{MH}^{+}\right)$; found 238.1220.

\section{2-Cyclopropyl-N,3-diphenylpropanamide (2b)}

${ }_{90}{ }^{1}$ H-NMR (300 MHz, $\left.\mathrm{CDCl}_{3}\right)(\delta, \mathrm{ppm}): 0.08(\mathrm{~m}, 1 \mathrm{H}), 0.24(\mathrm{~m}$, $1 \mathrm{H}), 0.57(\mathrm{~m}, 2 \mathrm{H}), 1.01(\mathrm{~m}, 1 \mathrm{H}), 1.68(\mathrm{~m}, 1 \mathrm{H}), 3.04(\mathrm{~m}, 2 \mathrm{H})$, $7.01(\mathrm{~m}, 1 \mathrm{H}), 7.20(\mathrm{~m}, 9 \mathrm{H}) ;{ }^{13} \mathrm{C}-\mathrm{NMR}\left(75 \mathrm{MHz}, \mathrm{CDCl}_{3}\right)(\delta$, ppm): 4.3, 4.8, 13.4, 38.7, 55.4, 120.1, 124.2, 126.2, 128.3, 128.8, 129.1, 137.6, 139.5, 172.6; Exact Mass (HRMS): required for ${ }_{95} \mathrm{C}_{18} \mathrm{H}_{19} \mathrm{NO}$ : $266.1545\left(\mathrm{MH}^{+}\right)$; found 266.1548. The X-Ray structure and data of $\mathbf{2 b}$ are deposited in the Cambridge Crystallographic Data Centre (CCDC 860535 \& 860536).

\section{Computational methods}

DFT calculations have been performed using B3LYP exchange- 
correlation functional together with the standard $6-31+G(d)$ basis set. ${ }^{15}$ For the studied open-shell species, the spin-unrestricted formalism (UB3LYP) was employed. The S2 expectations for the doublet states of all radical anions showed an ideal value of 0.750 5 after spin annihilation, so the geometries and the energetics are reliable for this study. Optimizations were carried out using the Berny analytical gradient optimization method. ${ }^{18}$ The stationary points were characterized by frequency calculations in order to verify that the transition structures (TSs) had only one imaginary

10 frequency. The intrinsic reaction coordinate (IRC) ${ }^{19}$ path was traced in order to check the energy profiles connecting each TS with the two associated minima of the proposed mechanism, using the second order González-Schlegel integration method. ${ }^{20}$ The electronic structures of stationary points were analysed by 15 the natural bond orbital (NBO) method. ${ }^{21}$ The solvent effects on the mechanism of the ring splitting have been considered through UB3LYP/6-31+G(d) single-point calculations at gas-phase stationary geometries using self-consistent field reaction field $(\mathrm{SCRF})^{16}$ method based on the polarizable continuum model ${ }_{20}$ (PCM) of Tomasi's group. ${ }^{16}$ As the solvent used in the experimental work was acetonitrile, we have selected its dielectric constant $\varepsilon=36.64$. Thermodynamic calculations were made with the standard statistical thermodynamics at $298.15 \mathrm{~K}$ and $1 \mathrm{~atm}$. Harmonic vibrational frequencies were scaled by a 25 factor of $0.96 .^{22}$ All calculations were carried out with the Gaussian09 suite of programs. ${ }^{23}$

\section{Acknowledgements}

Financial support from the MICINN (Grants CTQ-2010-14882, CTQ-2009-13699 and JCI-2010-06204), from CSIC (JAEDOC 30 101-2011) and from the UPV (Grant No. 20100994 and MCI

Program) is gratefully acknowledged.

\section{Notes and references}

${ }^{a}$ Departamento de Química/Instituto de Tecnología Química UPV-CSIC, Universitat Politécnica de València, Camino de Vera s/n, 46022, 35 Valencia, Spain E-mail: mcjimene@qim.upv.es; mmiranda@qim.upv.es

${ }^{b}$ Departamento de Química Orgánica, Universidad de Valencia, Dr.

Moliner 50, E-46100, Burjassot, Valencia, Spain.

$\uparrow$ Electronic Supplementary Information (ESI) available: [Spectroscopic characterization, X-Ray data of $\mathbf{2} \mathbf{b}$, and geometries of the stationary 40 points involved in several reactions; UB3LYP/6-31+G(d) Cartesian coordinates (78 pp.)]. See DOI: 10.1039/b000000x/

1 (a) A. Brandi, S. Cicchi and F. M. Cordero, Chem. Rev., 2008, 108 3988-4035; (b) F. P. Cossio, A. Arrieta and M. A. Sierra, Acc. Chem. Res., 2008, 41, 925-936; (c) B. Alcaide, P. Almendros and C.

45 Aragoncillo, Chem. Rev., 2007, 107, 4437-4492; (d) S. France, A Wheatherwax, A. E. Taggi and T. Lectka, Acc. Chem. Res., 2004, 37, 592-600; (e) B. Alcaide and P. Almendros, Chem. Soc. Rev., 2001, 30, 226-240; (f) I. Ojima, Acc. Chem. Res., 1995, 28, 383-389.

2 (a) F. von Nussbaum, M. Brands, B. Hinzen, S. Weigand and D.

50 Häbich, Angew. Chem., Int. Ed., 2006, 45, 5072-5129; (b) G. S. Singh, Mini-Rev. Med. Chem., 2004, 4, 69-92; (c) G. S. Singh, MiniRev. Med. Chem., 2004, 4, 93-109; (d) J. D. Buynak, Curr. Med. Chem., 2004, 11, 1951-1964; (e) G. Veinberg, M. Vorona, I. Shestakova, I. Kanepe and E. Lukevics, Curr. Med. Chem., 2003, 10, 1741-1757; (f) M. Kidwai, P. Sapra, K. R. Bhushan, Curr. Med. Chem., 1999, 6, 195-215; (g) Chemistry and Biology of $\beta$-Lactam Antibiotics, eds. R. B. Morin and M. Gorman, Academic Press, New York, USA, 1982; (h) D. Nathwani, M. J. Wood, Drugs, 1993, 45, 866-894.
603 (a) M. B. Jackson, L. N. Mander and T. M. Spotswood, Aus. J. Chem., 1983, 36, 779-788; (b) M. E. Speeter and W. H. Maroney, J. Am. Chem. Soc., 1954,76, 5810-5811; (c) J. N. Wells and O. R. Tarwater, J. Pharm. Sci., 1971, 60, 156-157.

4 (a) D. Ardura and T. L. Sordo, J. Phys. Chem. A, 2003, 107, 10171-

65 10176; (b) B. Alcaide and P. Almendros, Synlett, 2002, 3, 381-393; (c) B. K. Banik, K. J. Barakat, D. R. Wagle, M. S. Manhas and A. K. Bose, J. Org. Chem., 1999, 64, 5746-5753; (d) B. Alcaide, M. Miranda, J. Pérez-Castells and M. A. Sierra, J. Org. Chem., 1993, 58, 297-298; (e) B. Alcaide, J. Pérez-Castells, C. Polanco and M. A. Sierra, J. Org. Chem., 1995, 60,6012-6016.

5 (a) M. Fischer, Chem. Ber., 1968, 101, 2669-2678; (b) E. Rossi, G. Abbiati and E. Pini, Tetrahedron, 1999, 55, 6961-6970; (c) R. Alcazar, P. Ramirez, R. Vicente, M. J. Mancheño, M. A. Sierra and M. Gomez-Gallego, Heterocycles, 2001, 55, 511-521.

756 (a) J. M. R. Narayanam and C. R. J. Stephenson, Chem. Soc. Rev., 2011, 40, 102-113; (b) C. B. Harrison, L. L. O`Neil and O. Wiest, $J$. Phys. Chem. A, 2005, 109, 7001-7012; (c) M. G. Friedel, M. K. Cichon and T. Carell, Org. Biomol. Chem., 2005, 3, 1937-1941; (d) R. Perez-Ruiz, M. A. Izquierdo and M. A. Miranda, J. Org. Chem.,

80 2003, 68, 10103-10108; (e) Y. Wang, P. P. Gaspar and J.-S. Taylor, J. Am. Chem. Soc., 2000, 122, 5510-5519; (f) A. Joseph, G. Prakash and D. E. Falvey, J. Am. Chem. Soc., 2000, 122, 11219-11225; (g) G. Prakash and D. E. Falvey, J. Am. Chem. Soc., 1995, 117, 1137511376.

${ }_{85} 7$ Working electrode: $\mathrm{Au}$, counter electrode: $\mathrm{Pt}$; electrolyte: tetrabutylammonium perchlorate; scan: $250 \mathrm{mV} \mathrm{s}^{-1}$.

8 D. Rehm and A. Weller, Isr. J. Chem., 1970, 8, 259-271.

9 I. Andreu, J. Delgado, A. Espinos, R. Perez-Ruiz, M. C. Jimenez and M. A. Miranda, Org. Lett., 2008, 10,5207-5210.

9010 N. Valentic, D. Mijin, G. Uscumlic, A. Marinkovic and S. Petrovic, Arkivoc, 2006, 12, 80-90.

11 T. Sheradsky and D. Zbaida, J. Org. Chem., 1980, 45, 2165-2169.

12 Z.-W. Chen, H.-F. Jiang, X.-Y. Pan and Z.-J., Tetrahedron, 2011, 67, 5920-5927.

9513 (a) R. De Kimpe, R. Verhè, L. De Buyk and N. Schamp, J. Org. Chem., 1980, 45, 5319-5325; (b) P. Schneider, J. Am. Chem. Soc., 1968, 90, 988-992.

14 (a) N. C. De Lucas, J. C. Netto-Ferreira, J. Andraos and J. C. Scaiano, J. Org. Chem., 2001, 66, 5016-5021; (b) G. Raspoet, M. T. Nguyen, S. Kelly and A. F. Hegarty, J. Org. Chem., 1998, 63, 96699677; (c) A. G. Schultz and Y. S. Kulkarni, J. Org. Chem., 1984, 49, 5202-5206.

15 (a) A. D. Becke, J. Chem. Phys., 1993, 98, 5648-5652; (b) C. Lee, W. Yang and R. G. Parr, Phys. Rev. B, 1988, 37, 785-789; (c) Ab initio

105 Molecular Orbital Theory, eds: W. J. Hehre, L. Radom, P. v. P. Schleyer and J. A: Pople, Wiley, New York, USA, 1986.

16 (a) J. Tomasi and M. Persico, Chem. Rev., 1994, 94, 2027-2094; (b) Quantum Chemical and Statistical Theory of Solutions-A Computational Approach, eds: B. Y. Simkin and I. Sheikhet, Ellis

110 Horwood, London, England, 1995; (c) E. Cances, B. Mennucci and J. Tomasi, J. Chem. Phys., 1997, 107, 3032-3041; (d) M. Cossi, V. Barone, R. Cammi and J. Tomasi, J. Chem. Phys. Lett., 1996, 255 , 327-335; (e) V. Barone, M. Cossi and J. Tomasi, J. Comput. Chem., 1998, 19, 404-417.

11517 M. Miura, M. Enna, K. Okuro and M. Nomura, J. Org. Chem., 1995, 60, 4999-5004.

18 a) H. B. Schlegel, J. Comput. Chem. 1982, 3, 214-218; b) Modern Electronic Structure Theory, eds: H. B. Schlegel and D. R. Yarkony, World Scientific Publishing, Singapore, China, 1994.

12019 K. Fukui, J. Phys. Chem. 1970, 74, 4161-4163.

20 (a) C. González and H. B. Schlegel, J. Phys. Chem. 1990, 94, 55235527; (b) C. González and H. B. Schlegel, J. Chem. Phys. 1991, 95, 5853-5860.

21 (a) A. E. Reed, R. B. Weinstock and F. Weinhold, J. Chem. Phys.

125 1985, 83, 735-746; (b) A. E. Reed, L. A. Curtiss and F. Weinhold, Chem. Rev. 1988, 88, 899-926.

22 A. P. Scott, L. Radom, J. Phys. Chem. 1996, 100, 16502-16513.

23 Gaussian 09, Revision A.1, M. J. Frisch, G. W. Trucks, H. B. Schlegel, G. E. Scuseria, M. A. Robb, J. R. Cheeseman, G. Scalmani, 130 V. Barone, B. Mennucci, G. A. Petersson, H. Nakatsuji, M. Caricato, 
X. Li, H. P. Hratchian, A. F. Izmaylov, J. Bloino, G. Zheng, J. L.

Sonnenberg, M. Hada, M. Ehara, K. Toyota, R. Fukuda, J. Hasegawa, M. Ishida, T. Nakajima, Y. Honda, O. Kitao, H. Nakai, T. Vreven,

Jr. J. A. Montgomery, J. E. Peralta, F. Ogliaro, M. Bearpark, J. J. Heyd, E. Brothers, K. N. Kudin, V. N. Staroverov, R. Kobayashi, J.

Normand, J., K. Raghavachari, A. Rendell, J. C. Burant, S. S. Iyengar, J. Tomasi, M. Cossi, N. Rega, N. J. Millam, M. Klene, J. E. Knox, J. B. Cross, V. Bakken, C. Adamo, J. Jaramillo, R. Gomperts, R. E. Stratmann, O. Yazyev, A. J. Austin, R. Cammi, C. Pomelli, J. W. Ochterski, R. L. Martin, K. Morokuma, V. G: Zakrzewski, G. A. Voth, P. Salvador, J. J. Dannenberg, S. Dapprich, A. D. Daniels, Ö. Farkas, J. B. Foresman, J. V. Ortiz, J. Cioslowski, D. J. Fox, Gaussian, Inc., Wallingford CT, 2009. 